\title{
GENETIC DIFFERENTIATION BETWEEN ENGLISH AND FRENCH POPULATIONS OF THE SATYRID BUTTERFLY PARARGE MEGERA
}

\author{
CHARLES G. OLIVER \\ Museum of Comparative Zoology, Harvard University, Cambridge, \\ Massachusetts, U.S.A.
}

Received 12.xi.71

\section{INTRODUCTION}

Great Britain has been separated from continental Europe by an ocean barrier for about 6000 to 7000 years (West, 1968). Within this time visible differences in phenotypic appearance have evolved between British and Continental populations of a number of animals. Some examples are the squirrel Sciurus vulgaris L., the butterflies Papilio machaon L. and Lycaena dispar Haworth and the hare Lepus europaeus Pallas. However, considering the size of the total British fauna, there are relatively few species for which the English Channel forms the division between a described endemic British subspecies and the Continental subspecies. The relative infrequency of clearly visible differentiation of British populations may be due to one or more of the following possibilities:

(a) Most species have had insufficient time to evolve an endemic British subspecies.

(b) Gene exchange between Britain and the Continent is sufficient to swamp the differential effects of selection.

(c) Environmental conditions in the two areas are so similar as to result in little difference in selective pressure.

(d) Genetic differentiation within species need not be directly reflected by differentiation in phenotypic appearance.

Insular subspecies can be evolved in a surprisingly short time. The St Kilda race of the house mouse, Mus musculus L., apparently has evolved within historic times (Darling and Boyd, 1964), and populations of house sparrows inhabiting urban "islands" in the United States have become visibly distinct within about 100 years (Johnston and Selander, 1964, 1971). Possibility $(a)$ is therefore very unlikely. Possibility $(b)$ is very probable for many migratory species, such as the butterflies Pieris rapae L. and P. brassicae L., which often migrate in large numbers into Britain from the Continent (Ford, 1945). For most non-migratory species, then, we must conclude that either the individual is tolerant of a range of environmental conditions that includes those of Britain and the adjacent Continent and need not adapt to local conditions, or that there is significant genetic differentiation between populations separated by the Channel, but this differentiation is not revealed by differences in phenotypic appearance.

During August 1970 I was able to collect livestock for laboratory culture of the satyrid butterfly Pararge megera L. from southern England (Oxford) and the north-west coast of France (Boulogne). P. megera is a common species which occurs in grassy meadows and along roadsides. Although 
colonies may occupy extensive areas of suitable habitat, it is likely that individuals stay within a restricted home range. Single individuals of the small colony sampled at Oxford, recognisable by certain wing damage, were seen day after day sunning themselves on the same patches of bare earth. Other satyrid species, such as Maniola jurtina L. (Dowdeswell, Fisher and Ford, 1949) and Euptychia hermes Fab. (Emmel, 1968), show very limited individual motility, and no European or North American species are known migrants. Even though the chance of gene exchange between the Oxford and Boulogne populations is small, there is no apparent difference in phenotypic appearance. At the same time the species is so common and the range so relatively continuous in southern England that it is highly likely that little genetic differentiation exists over a transect between Oxford and the south-eastern coast of England. For these reasons $P$. megera seemed an excellent species to use in an investigation of the effect of a long-standing barrier to gene exchange between the separated parts of a discontinuous range.

\section{Methods}

Laboratory cultures were begun with two wild-fecundated females from each of the populations. The British and French $F_{1}$ broods were reared simultaneously, interpopulation and control matings were made among the $\mathrm{F}_{1}$ adults, and the hybrid broods reared simultaneously with control broods of both parental stocks. The $F_{1}$ hybrid adults were then backcrossed to these parental type control broods. During the breeding work observations were made on egg fertility (eggs showing visible embryonic development/ total number laid), embryonic viability (eggs hatching/number fertile), developmental rates, larval and pupal survival, fecundity, and sex ratio within broods. The cultures were maintained under standardised conditions $\left(26^{\circ} \mathrm{C}\right.$.; $16 \mathrm{hr}$. light $/ 24 \mathrm{hr}$.). Larvae were reared individually in glass shell vials and fed on cock's-foot grass (Dactylis glomerata L.) gathered from the area of the Oxford colony.

Control, $F_{1}$ hybrid and backcross data on fertility, embryonic viability, mortality and sex ratio were compared for difference using Wilcoxon's Two-Sample Statistic. Developmental periods were estimated by calculating 95 per cent. and 99 per cent. confidence intervals for the medians of the distributions, and fecundity was treated using the Mann-Whitney test.

To separate incompatibility effects from those caused by inbreeding, backcross fertility and hatchability were scaled by allowing for the expected reduction due to inbreeding depression before the significance tests were done. This method assumes the amount of depression to be a linear function of the degree of inbreeding since the allowances were based on data gathered from sibling matings within each parental culture. Inbreeding data from studies such as that by Dobzhansky, Spassky and Tidwell (1963) support the validity of this procedure.

\section{Results}

(i) Egg fertility and embryonic viability

Although there was no significant overall reduction in egg fertility or embryonic viability in the $F_{1}$ hybrid brood eggs, fertility was much more 


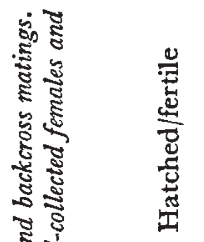

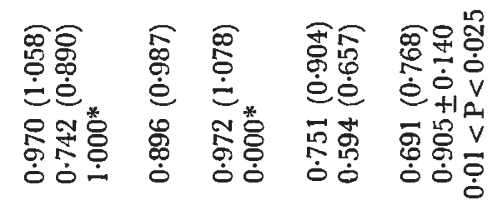

군

s.

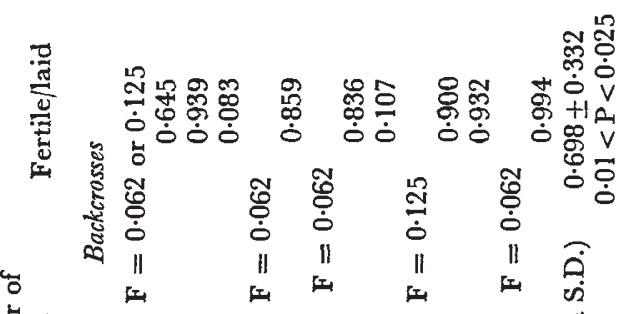

छ.

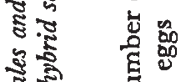

हี ริ

要

ปั.

ธี है

تี

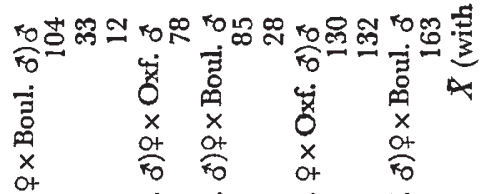

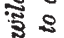

हैํํㅇ

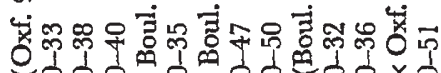

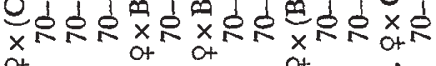

च छ

范 峁 嵌

要空

敢

范葶

总

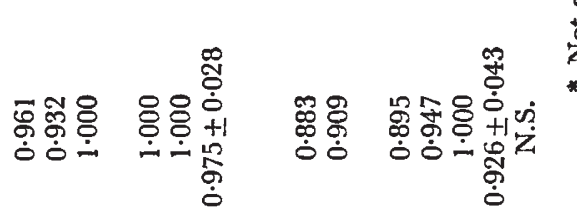

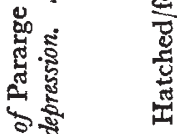

然

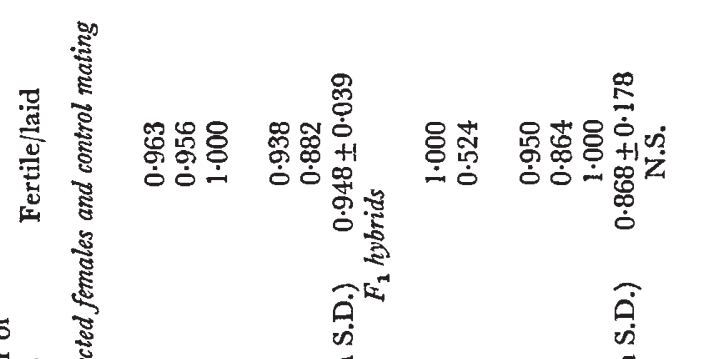

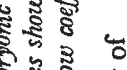

है

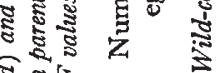

胥.

हैँ

켱

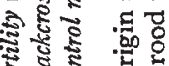

密造

令

กำ

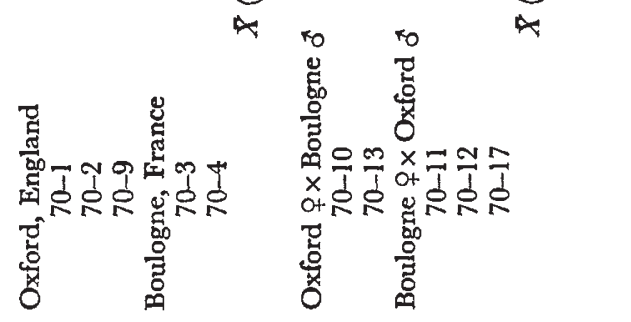


variable than in the control broods (table I). There were significant reductions $(0.01<\mathrm{P}<0.025)$ in egg fertility and embryonic viability in the backcross broods. There were an additional 9 control, I interpopulation cross and 13 backcross matings which produced no fertile eggs or a total of fewer than 10 eggs and are not included in table $\mathrm{I}$.

\section{(ii) Developmental periods}

There was probably a slight difference between the English and French control females in the length of the developmental period from the hatching of the eggs until the emergence of the adults (table 2), although there was no significant difference when the sexes were considered together. The $F_{1}$ hybrid broods developed slightly more rapidly than either parental stock. Because of their high mortality rate, not enough data are available for a proper comparison of the developmental periods of the backcross broods.

TABLE 2

Medians of developmental periods from hatching of the egg until eclosion of the adult for Pararge megera populations from England and France and their $F_{1}$ hybrids and backcrosses

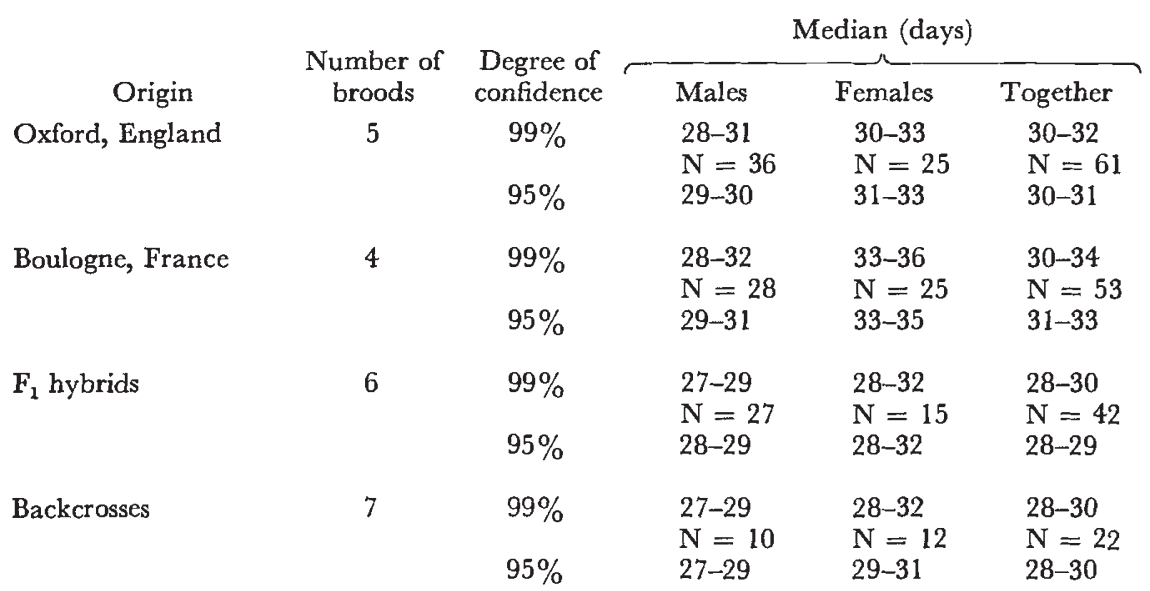

(iii) Survival

Survival in the $\mathrm{F}_{1}$ hybrid broods did not differ significantly from that in the control broods. In the backcrosses, however, larval and overall survival were significantly reduced (table 3 ). This does not reflect a reduction in vigour due to inbreeding, since there was no significant decrease in viability after hatching of the eggs in four control broods from sibling matings.

\section{(iv) Fecundity}

There was no demonstrable difference in total egg production per individual between females of the parental broods (average 45.7 eggs/female; $N=18$ ) and of the $F_{1}$ hybrid broods (average $88.5 \mathrm{eggs} /$ female; $N=4$ ).

\section{(v) Sex ratio}

There was no significant difference between the sex ratio (including successful emergences and fully developed adults dying immediately before 
eclosion) of the control broods $(7500: 56$ 우 $=1.00: 0.75)$ and of the $F_{1}$ hybrid broods $(31$ 후: 18 우 $=1.00: 0 \cdot 58)$. Too few backcross adults emerged for statistical analysis, but the total sex ratio $(11 \delta \hat{0}: 13$ 우우 $=$ $1.00: 1.18)$ may indicate decreased male viability.

TABLE 3

Mortality of Pararge megera control, $F_{1}$ hybrid and backcross broods during various developmental stages after hatching of the eggs. Statistical tests refer to comparisons of entire series with controls

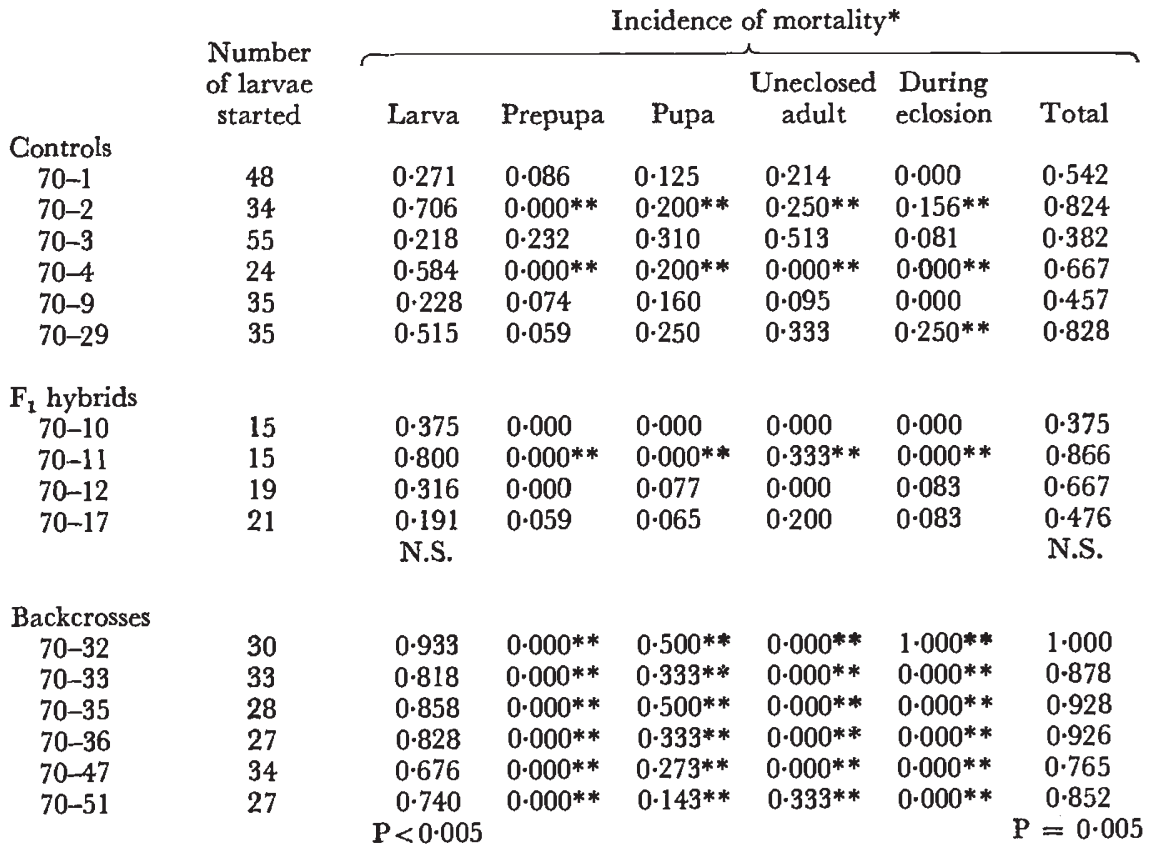

* Number dying during stage/no. entering stage.

$* * N<10$.

\section{Discussion}

In theory, hybridisation studies of the kind described here should show the degree of genetic differentiation between populations by providing a measure of the ability of the genetic material of the two to become integrated into a new, fit genotype and of the hybrid genotype to be integrated back into the parental types. As I have discussed at length in an earlier paper (Oliver, in press), genetic differentiation is not a random process, and because of differences in selective pressure, it is inevitable that some polygenic systems will change more than others. To provide a view of real differentiation rather than just of sharp incompatibility in a few polygenic systems, all the observations made here on $P$. megera must be used together in any final assessment of the results.

The increased developmental rate of the $F_{1}$ hybrids reflects the positive heterotic effect that usually occurs when crosses are made between geographically widely separated populations (e.g. Vetukhiv, 1954). The low fertility of the backcross eggs may indicate a reduction in the ability of the 
$F_{1}$ hybrid adults to produce viable gametes or may be due to very early embryo mortality. The lowered viability of the backcross broods all through development demonstrates the difficulty of fully integrating genetic material from the two populations to produce a genotype as fit as either parental type. The overall picture presented by the results is that the two populations show rather general differentiation with small differences scattered through the genotype. There is no evidence of very different polygenic systems, whose combination might produce almost total inviability of one sex, as in the ctenuchid moth Cisseps fulvicollis Hübner (Oliver, 1972), sexual mosaicism, as in the satyrid butterfly Coenonympha tullia L. (Ford, 1949), or abnormal emergence patterns, as in the nymphalid butterfly Phyciodes tharos Drury (Oliver, 1972).

These results are generally similar to those for other species of Lepidoptera when populations 500 to 2000 miles apart in a continuous range are crossed (Oliver, 1972), but in the absence of more complete data for $P$. megera no comparison can be made between the degree of genetic differentiation that exists across the English Channel and may exist across wide areas of continuous range on the Continent. Nor, unfortunately, can the EnglishFrench situation be compared, for example, to the relationship between $P$. megera on the Italian mainland and the phenotypically distinct populations on Sardinia and Corsica.

The main value, then, of the results presented here is that they allow a time scale to be attached to the differentiation of the English and French populations. According to Beirne (1952), the climate during the last glaciation was such that $P$. megera could have ranged no further north than the temperate land where the English Channel is today. The warming of the British climate would have allowed the extension of the range northward at least as far as its present limits, while at the same time (about 6000 years ago), the rising sea level separated the English population from that on the Continent. During the time that England and France have been separated there have been repeated, cyclic changes in the climate of the area. Repeated adaptation to climatic changes may account for a portion of the genetic difference between the Oxford and Boulogne populations.

\section{Summary}

1. There are relatively few species for which the English Channel forms the division between endemic British and Continental subspecies. For non-migratory species either there has been little selective pressure toward local adaptation, or genetic differentiation is not directly reflected in the visible phenotype.

2. Populations of Pararge megera from Oxford, England, and Boulogne, France, were crossed and backcrossed and observations made on control, hybrid and backcross fertility, viability, fecundity, developmental rate and sex ratio.

3. Differentiation between the populations was revealed by a significant increase in developmental rate in the $F_{1}$ hybrid broods and in reductions in egg fertility and viability in the backcross broods.

4. The genetic differentiation between the English and French populations has occurred within the last 6000 years. It may be partly due to differences in adaptation to repeated climatic changes. 
Acknowledgments.--This research was supported in part by a Grant-in-Aid of Research from The Society of the Sigma Xi. I am grateful to the Hope Department of Entomology, University of Oxford, for the use of laboratory facilities during my visit there in 1970 and 1971. Dr Robert Angus and Mr C. A. O'Toole made especially helpful comments and suggestions during the course of this work and in the preparation of the manuscript.

\section{REFERENCES}

Berrne, B. P. 1952. The Origin and History of British Fauna. Methuen and Co., London. DARLING, F. F., AND BOYD, J. M. 1964. The Highlands and Islands. Collins, London. DOBZHANSKY, TH., SPASSKY, B., AND TIDWELL, T. 1963. Genetics of natural populations. XXXII. Inbreeding and the mutational and balanced genetic loads in natural populations of Drosophila pseudoobscura. Genetics, 48, 361-373.

DOWDESWELL, W. H., FISHER, R. A., AND FORD, E. B. 1949. The quantitative study of populations in the Lepidoptera. 2. Maniola jurtina L. Heredity, 3, 67-84.

EMMEL, T. c. 1968. The population biology of the Neotropical satyrid butterfly, Euptychia hermes. I. Interpopulation movement, general ecology, and population sizes in lowland Costa Rica (dry season, 1966). F. Res. Lepid., 7, 153-165.

FORD, E. B. 1945. Butterflies. Collins, London.

FORD, E. B. 1949. Early stages in allopatric speciation. In Genetics, Paleontology, and Evolution (G. L. Jepsen, E. Mayr, and G. G. Simpson, eds.). Princeton Univ. Press, Princeton, New Jersey.

JOHNSTON, R. F., AND SELANDER, R. K. 1964. House sparrows: rapid evolution of races in North America. Science, 144, 548-550.

JOHNSTON, R. F., AND SELANDER, R. K. 1971. Evolution in the house sparrow. II. Adaptive differentiation in North American populations. Evolution, 25, 1-28.

OLIVER, c. G. 1972. Genetic and phenotypic differentiation and geographic distance in four species of Lepidoptera. Evolution, 26 (in press).

VETUKHIV, M. 1954. Integration of the genotype in local populations of three species of Drosophila. Evolution, 8, 241-251.

WEST, R. G. 1968. Pleistocene Geology and Biology. Longmans, Green and Co., London. 